\title{
MARITIME CONNECTIONS AND CROSS-CULTURAL CONTACTS BETWEEN THE PEOPLES OF THE NUSANTARA AND THE EUROPEANS IN THE EARLY EIGHTEEN CENTURY
}

\author{
Hendrik E. Niemeijer \\ The Corts Foundation, Indonesia \\ Talavera Office Park, $28^{\text {th }}$ Floor, Jl. T. B. Simatupang Kav. 22-26, Jakarta, 12430 \\ Corresponding Author: he.niemeijer@gmail.com \\ Diterima/ Received: 4 Desember 2015; Disetujui/ Accepted: 28 Januari 2016
}

\begin{abstract}
In this paper, I would like to discuss two extraordinary tales of two rather ordinary individuals in the service of the Dutch East India Company (henceforth: VOC), the first a Dutchman, Jacob Janssen de Roy, and the second a German, Georg Naporra (1731-1793). It is important to understand that all cross-cultural contacts between the peoples in the archipelago and westerners depended on seaborne trade and the vessels which plied the maritime routes. This was the only means of transportation and communication. As a consequence, cross-cultural contacts took place mainly in the port cities and coastal trading outposts. This can be clearly seen in the cases of our two ordinary Europeans: Jacob de Roy and Georg Naporra.
\end{abstract}

Keywords: Maritime Connections; Cross-Cultural Contact

\section{INTRODUCTION}

Asian-European relations were largely a one-way maritime traffic between Europe and Asia during the 18th century. No Asian ships went to Europe. Thousands of Europeans embarked on a journey from London or Amsterdam to Asia, but during the seventeenth century hardly any Asians reached Europe. It was the policy of the Dutch United East India Company (the biggest European trading company in Asia until around 1750) not to bring Asian spouses or personnel to the Dutch Republic. The British took a more pragmatic approach. Half the personnel of the British Navy in the 18th century were black. Most from Africa but a fair few from Asia and port cities like Liverpool and Bristol by the late eighteenth century had sizeable nonEuropean populations Somalis in particular as they took service in large numbers in the merchant navy. We can still notice their presence in modern English language with terms like 'shampoo' and 'tiffin' and 'chota-hazari' coming direct from the Urdu, Hindi and Hindustani.

Computer calculations of the personnel on board VOC vessels delivers a clear number: between 1700-1789 an average of 20,000 men a year worked in one of the twenty-five trading establishments of the Dutch United East India Company in Asia, or on board of one of the Company ships in the intra-Asian routes connecting these trading points (Lequin \& Titsingh, 2002: 13). 
Everyone of these 20,000 men observed more or less the world of Monsoon Asia. But hardly one of them left a diary or travelogue. One wonders what kind of image of Asia, views of Asian people and knowledge of Asian society and culture was transferred by these non-elite Europeans to their own home town or village, if indeed they survived the rigours of the long sailing voyages.

In this paper, I would like to discuss two extraordinary tales of two rather ordinary individuals in the service of the Dutch East India Company (henceforth: VOC), the first a Dutchman, Jacob Janssen de Roy, and the second a German, Georg Naporra (1731-1793). It is important to understand that all cross-cultural contacts between the peoples of the archipelago and westerners depended on seaborne trade and the vessels which plied the maritime routes. This was the only means of transportation and communication. As a consequence, cross-cultural contacts took place mainly in the port cities and coastal trading outposts. This can be clearly seen in the cases of our two ordinary Europeans: Jacob de Roy and Georg Naporra.

Jacob de Roy was a citizen in Batavia who was prosecuted by his enemies in 1691. He secretly escaped Batavia in a private trader, an Indonesian-crewed vessel, but failed to reach the Straits of Melaka to catch an English ship back to Europe. Instead, he was stranded on the east coast of Kalimantan (Borneo), and stayed in Banjarmasin for several years (1691-94), after which he became a trader in Aceh (1695-96). During all these years what was the nature of his interactions with the people of these independent Nusantarian port towns? His case is important and his observations reliable (Lach and Kley, 1993: 1390).

It is one of those very rare cases of a Dutchman surviving in an often-hostile Nusantarian environment without VOC protection. How was he treated? How did he feel about the people who helped him or those who wished him ill and threatened him? His hitherto unknown story is one of the most interesting cross-cultural contacts, which I have come across in the early eighteenth-century VOC archives. ${ }^{1}$

Georg Naporra (1731-1793), meanwhile, was the son of a Prussian (North German) farmer. In 1752, he took service with the VOC, just one of thousands of ordinary Europeans who ended up in Company employ after lengthy travels around Asia. What did a common man like Naporra see in Asia? How did he perceive the lands and the people with whom he came into contact and what was his particular European take on his Asian experiences? $?^{2}$

From a scientific point of view, Georg Naporra's case is unique. His five hundred-page life story entitled Öst-Indische Reise (East Indies Journey) was only discovered by the historian and journalist Roelof van Gelder in 1987 in the library of the Maritime Museum in Rotterdam (van Gelder, 1987: 120). Nobody knows how and when it was included in the library collection and no one had ever studied it. This shows how new discoveries can still be made, and that at the social level of an ordinary seaman like Naporra, our understanding of cross-cultural contacts is still very sketchy.

Such cross-cultural contacts have so far been dominated by published travelogues, which can be found in libraries the world over. One of the most famous of these published accounts is the OostIndische voyage of Wouter Schouten (16381704), a Haarlem surgeon who worked on VOC ships in Asia (Breat \& Haeften, 2003). When one compares this work with the memoirs of a senior naval officer like Commodore Maurits Ver Huell a century later, the differences are striking. The latter's 1815-1819 travelogue describes a different world, one that has become more comprehensible and malleable under European colonial control. But also one influenced by a new cultural atmosphere, Romanticism, which placed a new emphasis on emotion, mystery and sentiment.

Between these two worlds lies what is know to historians as the 'long eighteenth century', a 
term used to describe the $1680-1815$ period. This was a period of transition, one of rapid social, economic and political change due to the twin industrial and political revolutions, which transformed the late eighteenth-century European and Atlantic world. Beginning in England around 1760, the Industrial Revolution, would transform the European economies through the introduction of steam power and mass production: a single mechanised power loom (1785) could produce more cloth in an hour than a handloom weaver could make in an entire year. Meanwhile, the French Revolution of 1789 introduced a new political order based on democracy and citizens' rights. 'Happiness [le Bonheur] [of citizens] is a new idea in Europe' is how the French Revolutionary leader St. Just put it. The European ancien regime was at an end.

The impact of the eighteenth-century economic, political and cultural transformations (industrialization, civil revolutions, the Enlightenment and a simultaneous Scientific Revolution) meant that exotic stories about strange and unknown worlds were no longer accepted as reliable. Instead, the history of the world began to be recorded based on empirical material available to all and no longer informed by speculative theological writings. Humankind was now seen to share fundamental homogeneity and all civilizations were considered equally valuable and authentic (Ostarhammel \& Petersson, 2003: 55-57). But such open, cosmopolitan, Enlightenment-influenced attitudes disappeared during the course of the 19th century, when race theories, imperialism and the fundamental inequality of humankind became the norm, shaping the way in which Westerners perceived the non-European world.

\section{THE FUGITIVE JACOB DE ROY IN BANJARMASIN AND ACEH, 1691-1696}

Jacob de Roy - an exponent of the late seventeenth century and still half a fantasist - escaped from
Batavia with his Indonesian vessel and forty-onemen crew on 21 October 1691. He feared prosecution from the VOC's Council of Justice and had many enemies in Batavia. The plan was to sail through the Bangka Straits, and, passing through Johor and Melaka and make for Aceh. In Aceh he hoped to board a ship of 'whatever Christian nation' and go back Europe the soon the better. He was done with the VOC, with corrupted colonists, with the climate, with everything.

Unfortunately, near Bangka, on 6 November, the vessel ran into a powerful storm, which blew it onto the Kalimantan coast, a very unsafe area for during the months of November and December the rulers of Palembang, Billiton, Bangka and Johor sent their raiding vessels to the shores of Kalimantan. After a few months of misery, attacks from the indigenous Dayak, and marauding Bugis and Makassarese, De Roy and a handful of his remaining crew were taken to Banjarmasin. He presented himself as a friend of the Sultan of Banten Abdul Fadhl, as De Roy had taken part as a military officer during the 1682 military campaign, which restored Sultan Haji (r. 1682-1687) on Banten's throne. He was accepted by the Sultan of Banjarmasin but not by his courtiers: De Roy tells how he was ordered to act as the medical doctor for the exiled prince of Sukadana in West Kalimantan, Pangeran Martaningrat, who lived under the protection of the Banjarmasin ruler. De Roy was also protected by the local Kapitan Cina or Head of the Chinese community (kampung), but was suspected as assassin by one of the court counsellors. After having gained admission to the Sultan, he was able to pass himself off as weapons' expert and carpenter. According to his own story, the Sultan and his two chief counsellors showed him the palace defence, including forty iron and bronze canon, which were partly sunk in the mud without proper gun carriages. De Roy convinced the nobles that he was the right person to make these carriages, if they could provide him with the right timber and skilled assistants. A deal was struck and 
De Roy even received half a dozen pieces of cloth from Macao to dress himself. Thus the initial hostile attitude changed into one of cooperation and friendship, to the great suspicion of the Portuguese who were purchasing pepper in Banjarmasin, and trying to get rid of De Roy by falsely accusing him of treachery. The Portuguese, according to De Roy, were trying to establish a stronghold near the pepper villages in order to secure a constant delivery of the product. Since it was in the Sultan's interest to defend himselfs against European intruders, this is why De Roy was permitted to stay on. At that time, Banjarmasin was an independent trading port, which was visited annually by between seven and twelve Chinese, Siamese and Johorese trading junks of 200, 300, lasten ship weight.

After his gaining acceptance at the Banjarmasin court, De Roy acted as advisor to the Sultan. One of the few illustrations in his book shows the contemporary European convention of depicting Asians with bare feet and without too many clothes. De Roy was given the permission to travel around the Banjarmasin hinterland to survey for gold and diamond mining locations. His notes on his travels through the interior of the sultanate, led to one of the earliest descriptions of the Banjarmasin state, including observations on the headhunting Dayak, by any European visitor. De Roy wrote that headhunting practices and the attacks by Dayak pirates (Iban) along the Banjar River or off the coast were targeted at the pepper traders and vessels carrying pepper from the interior. The lack of security due to these local Dayak pirate activities limited the sultanate's potential as a pepper exporter.

During his three-year sojourn in Banjarmasin De Roy sent several letters to Batavia to convince the Supreme Government to make a treaty with the sultan. He also tried to convince the sultan to ally himself with the VOC as a means of ridding himself of his enemies, whether Makasarese pirates, Portuguese or Dayak. But the main Banjarmasin leadership described by De Roy as 'rijksgrooten' (chiefs) or regents, mistrusted the Dutchman and pressed him to convert to Islam. De Roy escaped the town, planning to make for Sukadana in a small vessel, where he might purchase a bigger boat and sail to Aceh. But after twelve days at sea he could not keep the water out of his vessel and was shipwrecked once again on the Bornean coast with the chest of gold he was carrying to make his vessel purchase in Sukadana. After many dangerous encounters with the hostile local population, De Roy ended up in Banjarmasin again. After having been convicted and almost poisoned by the court, suddenly an English ship with a Sukadana pilot aboard appeared and cast anchor in the Banjarmasin roads, the first English ship ever to visit the sultanate according to De Roy. De Roy sent out his personal vessel full of fruits and other refreshments for the crew of the English ship together with a letter for the Captain detailing his personal situation and the narrative of his previous three years. Eventually, De Roy received the sultan's permission to depart, and with this English ship he finally reached Melaka in early 1696. After seventeen days riding at anchor in Melaka road, he took passage on another ship bound for Aceh, just in time before the local VOCofficials (Malacca was at this time a Dutch trading post) found out that the long sought-after fugitive, Jacob de Roy, was in the port.

De Roy describes the free city of Bandar Aceh as a flourishing trading port. Selling his gold and jewels, he purchased a wrecked English ship that was being sold at public auction. After repairing it, he sold the restored vessel, bought two shallops and with these two vessels, began trading on the Bengal coast. Once established in Aceh as a successful merchant, De Roy's house was usually full of foreign Danish, English, French, Armenians and 'Moorish' traders. He would spend the next two years (1694-96) in Aceh as a free trader, importing goods from India's east coast in return for gold.

De Roy's observations on the Aceh government of the last queen, Zainatuddin 
(reigned 1688-99), and her councils, confirm that the Acehnese queens exercised limited authority, having to await the outcome of the governing council meetings to take decisions. In De Roy's words: "it is not unkind to compare these council meetings with the league meetings of the kingdom of Poland", a body which was notorious throughout Europe for its lengthy discussions and inability to reach clear-cut decisions.

The defence of the city was weak, according to De Roy. As had been the case in Banjarmasin, most of the cannon were buried in the sand. Military know-how was scarce and the sultanate's defence works "nothing in the world according to the art of mathematics". Aceh depended on gold mining in its hinterland, which, in De Roy's view, made the people arrogant and lazy. The place was full of thieves, but strict syariah (Islamic) law was practiced and those thieves could easily loose feet and hands. The wealthiest citizens defended their property with their own small cannon and hand weapons.

The rest of his book De Roy devotes to his contacts with the English and French, who had been forced to leave Siam because of the Siamese popular Revolution of 1688, which led to the temporary expulsion of foreigners. Because of his knowledge of the various VOC outposts in Asia and their respective military capacity, the Supreme Government in Batavia eventually gave De Roy a pardon. It was simply too dangerous for the VOC of running the risk of De Roy taking service with the French. ${ }^{3}$ On his return to Batavia, De Roy gave all his papers and documents to the VOC authorities, and in return had all his debts paid off.

De Roy put pen to paper to write his memoirs shortly after his return to Batavia. His narrative covers his six years (1691-96) in Banjarmasin and Aceh. The most notable feature of is memoirs was his position as an independent trader for it was highly unusual for former VOC servants to stay in independent port cities without the protection of the Company. The most striking thing about De Roy's "cross cultural contacts" is that the environment was generally hostile. He could not have survived without the direct protection of the local rulers, namely, the sultan in Banjarmasin and Queen Zainatuddin in Aceh. Banjarmasin and its surroundings were more problematic than Aceh, since the latter was a world-renowned trading port and was much more cosmopolitan in culture and outlook. Aceh offered more freedom for a European free trader than Banjarmasin.

\section{A COMMON SAILOR FROM EAST PRUSSIA IN BATAVIA: GEORG NAPORRA}

Georg Naporra came from the independent kingdom of East Prussia, which used to be part of Poland, but became part of the Grand-Duchy or Margraviate of Brandenburg after becoming Protestant in 1525. Germany as a nation state was still a century and a half in the future. Keurvorst Frederik Wilhelm I (r. 1713-40), the second Prussian king, was known as the "soldier king" and under him Prussia became renowned for its strong army and fierce military discipline. Georg grew up in a farmer's family, briefly joining the army in his mid-teens, and then holding down several jobs in Mariënburg and Köningsberg (present-day Kaliningrad) but it was difficult to make a good living. He was always dependent on small shopkeepers and traders to earn his living, and always lived in unheated small rooms, which were very cold in the winter. His diary is full of small notes about the small sums of money he had to spend, his worries about his future, his lack of money to get married. He borrowed money from friends. And so his life continued on its petty and difficult course until one day the younger brother of his boss, Andries Steputsch, who was himself almost bankrupt, told him about the possibility of going to the East Indies. This was a good escape for Georg, who at that time was still just nineteen years old, impatient, and ready for an adventure.

At the beginning of the $18^{\text {th }}$ century, travelogues were already quite popular and 
available in local bookshops. One of the more popular books was the Ost-Indianische ReiseBeschreibung from Ernst Christoph Barchewitz from Thüringen, published in 1730. Barchewitz spent eleven years in Indonesia; first in Batavia, and later on the Banda and islands further to the southwest like Kisar. Barchewitz wrote in his foreword that so many hundreds of Germans had travelled to Asia, and so many had written travelogues, that Asia was becoming as equally well known as Germany itself (van Gelder, 1987: 121).

In 1751, one year before Georg's departure, Barchewitz's book had been reprinted and was almost certainly available in the local bookshops in Köningsberg. In 1719, Daniel Defoe's The Life and Strange Surprizing Adventures of Robinson Crusoe was published. The author was followed by dozens of followers who all wrote "Robinsonades", Robinson-like tales were particularly popular in Germany, so much so "that one could fill the River Rhine and Elbe with it" (van Gelder, 1987: 121). van Gelder supposes that these books were all available in Köningsberg and that Georg Naporra had at least knowledge of a number of such book titles. He also would have had a basic knowledge of the world map, and a positive image of Asia on the basis of the available information at the time derived mainly through travelogues.

How then did the young Georg Naporra view Asia? The ship Drie Papegaaien (Three Parots) anchored at Batavia road in June 1753, the same month that Governor-General Jacob Mossel (in office, 1750-61) was finishing his report on the health situation in the colonial capital: Aenmerkingen over Batavia's gesteldheid (van Gelder, 1987: 131). These comments on Batavia's unhealthy condition followed two decades of disease, during which Batavia, once renowned as the queen of he East had become known as the 'Graveyard of the East'. Three days after arrival all soldiers were taken off board. The crew of the ship had to stay on the ship. Georg tells how he bought foodstuffs with his own money, and how difficult it was for him to survive. His ship was taken to the shipyard on Pulau Onrust in the Bay of Batavia where there were important shipyards, where fifty crewmembers worked on the repair and maintenance of the ship. Georg described this as a period of 'slave labour'. Only on 2 July 1753, after having been seven months cooped up on the ship, and after receiving his three-month back-pay salary, did he receive permission to go into the colonial capital.

His description of Batavia is more or less similar with other visitors from Europe. ${ }^{4} \mathrm{He}$ condemns the 'black women' receiving sailors and soldiers as prostitutes; Batavia and its Castle are wonderful, better than Amsterdam or Danzig in Prussia with its Academie de Marine (Naval Academy); churches and town hall are splendid; European women are too pale and look exhausted; they are arrogant and don't have to do anything; the climate is disastrous and the military regiments of 'blacks' (Mardijkers and people of the Nusantara) walk barefoot. Non-Christian free Asians are allowed to carry a hat under their arm, but they were not allowed to wear it on their heads. Christian Mardijkers are allowed to dress as Europeans. Georg's observations were rather standard but this should not surprise as he only went two more times to the city for short visits during his two-and-a-half month stay on Onrust and on board his ship. He describes the constant coming and going of Asian vessels and large European ships in the port (van Gelder, 1987: 318-324).

After Batavia, the Drie Papegaaien set sail for India's west coast, crossing the Indian Ocean. In December 1753, the ship reached Surat, the port of Gujarat. Georg's judgement on this port city is very negative. It is a murderous place (moordkuil) and no ship is safe from pirates, even in the harbour. The city is dirty and chaotic, a cesspit (zwijnenstal). But he admired the ships of the Indian-Arab Muslims, which sailed back and forth from Jeddah carrying pilgrims. Although the ships were a bit smaller than European ships, the craftsmanship and quality was on a par with the 
best in Europe. He also admired the volume of trade in textiles, which attracted twelve VOC-ships per year from Batavia, and several other European ships. Trade was more flourishing there than in many a European town.

\section{CONCLUSION}

The question now is whether Georg Naporra's, Jacob Janssen de Roy and other Company servants' cross-cultural contacts with Asian people and settlements, and their short observations led to a positive or negative picture of Asia. It is important to study the contacts of these sailors and soldiers, because they formed the majority of people that came back in Europe, told their stories and expressed their opinions to close friends, family and wider circle.

That say that the contacts were not "cross cultural" in the sense that contacts between Europeans and Asians were limited to Asian places, and that information about Europe was scarce and limited to the Asian elite that were literate in the relevant European languages and had access to European newspaper and books, for instance the sultans of Banten who were close to the bookshops of Batavia. The accumulation of knowledge on Asia in Europe is inventoried extensively (Lach, 1993). Asia was not an unknown, exotic place anymore with strange people and even monsters, which had so excited European audiences in the sixteenth and seventeenth centuries. In the first half of the $18^{\text {th }}$ century Asia had lost its terrors, Europeans were drinking coffee and tea, wearing Asian cottons. Asia was no longer the 'theatre of maritime operations' for 'Gunpowder Empires' and 'Maritime Domains' as it had been in the sixteenth and the first half of the seventeenth centuries. In the first half of the eighteenth century, Asia was largely discovered. J. Osterhammel's book Die Entzauberung Asiens, first published in 1998 described how Asia was more and more perceived as just another civilization - albei a rather more exotic one - in the eighteenth century, with similar forms of government and ordered societies (Osterhammel, 2013). In Georg Naporra's and Jacob de Roy's works one can still find notions of 'uncivilized' or 'wild' people, but the overall judgement is surprisingly realistic and cosmopolitan. The fact that people like Naporra and thousands of other Germans, Dutch and English crossed oceans to see Asia, made Europeand Asian cities ever more cosmopolitan. In the second half of the eighteenth century, even a local port like Banjarmasin could not escape the influences from the wider world any more: it had lost its provincialism and had now been forced to cooperate with a major European player - the VOC - to loose a certain degree of economic independence.

\section{NOTES}

${ }^{1}$ There are several references to his story in the Daily Journals of Batavia Castle. Mona Lohanda and Hendrik E. Niemeijer (2014). Marginalia to the Daily Journals of Batavia Castle (1659-1799): A Digitized Contemporary Chronological Entry to Archives of The Dutch East India Company (VOC). Jakarta: Arsip Nasional Republik Indonesia/ The Corts Foundation. To be consulted at http://www.sejarah-nusantara.anri.go.id/.

${ }^{2}$ The most comprehensive and complete overview of published books 1600-1800 on Asia during the VOC erais J. Landwehr (1991). VOC: A Bibliography of Publications Relating to the Dutch East India Company, 1602-1800. Utrecht: Hes \& Graaf.

${ }^{3}$ England and the Dutch Republic became friendly nations after the Glorious Revolution of 1688, which placed the Dutch Stadhouder Willem III on the throne in England.

${ }^{4}$ M. Barend-van Haeften (1992). Oost-Indië gespiegeld: Nicolaas de Graaff, een schrijvend chirurgijn in dienst van de VOC (Zutphen: Walburg, 1992). 


\section{REFERENCES}

Lach and Kley (1993). Asia in the Making of Europe. Volume III: A Century of Advance. Chicago: The University of Chicago Press

Lohanda, Mona and Hendrik Niemeijer (2014). Marginalia to the Daily Journals of Batavia Castle (1659-1799): A Digitized Contemporary Chronological Entry to Archives of the Dutch East India Company (VOC). Jakarta: Arsip Nasional Republik Indonesia dan The Corts Foundation.

Landwehr, J. (1991). VOC. A Bibliography of Publications Relating to the Dutch East India Company, 1602-1800. Utrecht: Hes \& Graaf.

Fraassen, Chr. F. and Klapwijk, P. J. (2008). Herinnering aan een Reis naar Oost-Indië. Reisverslag en Aquarellen van Maurits Ver Huell, 1815-1810. Zutphen: Walburg.

Haeften, M. Barend-van (1992). Oost-Indië Gespiegeld: Nicolaas de Graaff, een schrijvend chirurgijn in dienst van de VOC. Zutphen: Walburg

Ostarhammel, Jürgen (2013). Die Entzauberung Asiens. Europa und die Asiatische Reiche im 18. Jahrhundert. München: C.H. Beck. 